\title{
Mechanism for Producer Services to Upgrade Value Chain from the Perspective of Spatial Networks
}

\author{
Rui Zhang ${ }^{1,3}$, Shuhan $\mathrm{Liu}^{1,2}$, Shaoyu $\mathrm{Wu}^{1, *}$ and Dabin Meng ${ }^{2}$ \\ ${ }^{I}$ Department of Management and Economics, Tianjin University, Tianjin 300072, China \\ ${ }^{2}$ School of Economics, Tianjin University of Commerce, Tianjin 300134, China \\ ${ }^{3}$ School of Computer Science and Technology, Hulunbuir College, Hulunbuir 021008, China
}

\begin{abstract}
The study aimed to analyze the function mechanism for producer services to upgrade value chain based on spatial networks, with regional domestic Export Sophistication Index for measuring the position of China's provinces in the global value chain. Using spatial econometrics model, the study set up a variety of spatial weight matrices, to empirically test the spatial networks' effect as a result of the producer services with changes in the positions of China's various provinces in the global value chain. Results indicate that: first, the producer services have an obvious spatial networks effect on upgrading of the various parts of China in the global value chain. Second, the estimated results of distance based spatial weights matrix model were contiguity based spatial weights matrix results, implying that space network effect is not limited to the neighboring provinces. Third, the spatial network effect of economic based weights matrix model was stronger than distance based spatial weights matrix model, which shows that today, the changing value chain of Chinese provinces is more inclined to "regional powerful combination", rather than "regional strength complementary".
\end{abstract}

Keywords: Producer services, Upgrade value chain, Spatial networks.

\section{INTRODUCTION}

Under the promotion of economic globalization and information revolution, products' value chain is creating spatial isolation with continuous deepening of intra-production specialization, to form global distribution of industrial value chain gradually [1]. Transnational corporations are engaged in manufacturing high value-added commodities and services, firmly occupying high-end links of value chain. However, in order to enter into global value chain with low environmental protection, the developing countries carry on low value-added outsourcing businesses of transnational corporations depending on low-cost comparative advantages of raw materials and labor forces faced with such potential risks as "comparative advantage trap", "international outsourcing trap", value chain "solidifying", and being "captured" for "waterfall effects". In addition, only minority of developing countries can realize automatic update of value chain [2], but majority of developing countries have been locked in the low side of global value chain for a long time [3]. For example, it is difficult for Pakistan, Sri Lanka and Bangladesh to achieve a breakthrough as they have been "indulged" in low-end links of global value chain for many years [4-8].

Path selection and influence factors of developing countries' upgrade value chain have been studied in the existing literatures. Humphrey and Schmitz [9] proposed that "path

*Address correspondence to this author at Department of Management and Economics, Tianjin University, Tianjin 300072, China;

Tel: +8613820546180; E-mail: wushaoyu@tju.edu.cn selection of upgrade value chain shall be conducted according to such four models as product upgrading, technology upgrading, function upgrading and chain upgrading". Numerous scholars thought that "upgrade value chain is a systems engineering, which is affected by economic growth, infrastructure, financial development, human capital and institutional environment" [10-12]. Some scholars indicated that "producer services play an important role in building leading national value chain of domestic enterprises" [1315], but they haven't realized significant influences of spatial networks formed by producer services on upgrade value chain. Promoted by information and internet technology revolution, highly developed producer services have built transnational corporations' leading global production networks and transnational corporations have realized integration of resources and market development around the world through the production networks, so as to maintain their position of "chain master".

In view of this, this paper shows that developing producer services rapidly is the key to breaking "low-end and solidified" value chain and China shall build producer service networks, including innovative network, financial network, logistics network and marketing network, and integrate resources and develop market in a wider spatial scale, so as to realize high-end expansion and extension of local enterprises to global value chain and to raise the position of various regions of China in global value chain. This paper is organized as follows. Firstly, the paper analyzes the function mechanism for producer services to upgrade value chain based on spatial networks; secondly, it measures the position of Chi- 
na's provinces in the global value chain with regional domestic Export Sophistication Index and analyses the change rule of provincial value chain. Thirdly, using spatial econometrics model, a variety of spatial weight matrices were set up to empirically tests the spatial networks' effect formed by the producer services with the variations in the positions of China's various parts in the global value chain. The study is of great theoretical and practical significance to high-end evolution of Chinese domestic enterprises to global value chain.

\section{ANALYSIS OF PRODUCER SERVICES' SPA- TIAL NETWORK EFFECT MECHANISM ON UPGRADE VALUE CHAIN}

The frame was analyzed by a theoretical model constructed in this paper, and producer services' spatial network effect mechanism on upgrade value chain was discussed referring to "cost discovery" model proposed by Hausmann, Hwang and Rodrik [16] for analyzing the influence factors of export technological level.

Firstly, it was supposed that the production function of a manufacturing enterprise is as follows:

$Y=A L^{\alpha} K^{\beta} N^{\gamma}$

Here , L, K, and $\mathrm{N}$ indicate labor force, physical capital and natural resources, respectively, and at the same time, we supposed constant returns to scale, namely $\alpha+\beta+\gamma=1$.

$\alpha \mathrm{A}$ indicates technical parameter when such factors combine for production. Large value of A implies the higher technological sophistication of manufactured products; in this way, the enterprise's position in global value chain is enhanced. A follows unanimous uniform distribution between $[0, h] . h$ is a constant, representing skills and technological endowment of a country. With larger $h$, enterprises of the country can be on the leading edge of productivity. In addition, $h$ can be regarded as knowledge input combination and a synthesis of producer service which can promote knowledge coupling and enhance knowledge efficiency. In the following function, $\quad h=f(D, F, O) \times P\left(W_{1}, W_{2}\right) \quad \mathrm{h}=\mathrm{f}(\mathrm{D}, \mathrm{F}, 0) \times$ $\mathrm{P}\left(\mathrm{W}_{1}, \mathrm{~W}_{2}\right) f$ indicates knowledge input combination; $D$ indicates internal knowledge, such as human capital, R\&D ability, and manufacturing level; $\mathrm{F}$ indicates external knowledge, such as FDI and import trade ; O indicates other factors affecting accumulation of internal and external knowledge, which can directly promote enterprises to realize scale economy and innovation level, such as foreign investment, import trade, infrastructure, institutional environment and innovation policy. $\mathrm{P}$ indicates producer service, and $W_{1}$ is a producer service in enterprises' productive process with intermediate input and a necessary input factor for enterprise production, which play an important role in promoting enterprises' professional level services, such as scientific and technological service, internal logistics, productive maintenance services, and non-banking finance service; $W_{2}$ indicates producer service network composed of enterprise products' service modules with external dependency and inde- pendent management, which are critical to coordination and layout of the whole production system in space, as well as assisting, lubricating, and reducing cost, such as innovative network, financial network, financial network, logistics network and marketing network.

Secondly, to confirm enterprise productivity level in accordance with "cost discovery" principle of Hausmann [17], each enterprise may choose to manufacture products with high productivity level, so that enterprises of a country can choose to imitate other products with high productivity level or to manufacture their own products after researching and developing new products. Assuming that the highest productivity level of a product is $A^{\max }$, imitation efficiency is $\theta$ and $0<\theta<1 ; \mathrm{t}$ enterprise (i) chooses to imitate other products with high productivity level when $A_{i}<\theta A^{\max }$ $\mathrm{A}_{\mathrm{i}}<\theta \mathrm{A}^{\mathrm{max}}$, while enterprise (i) chooses to manufacture its own products when $A_{i} \geq \theta A^{\max }$. We supposed that there are $\mathrm{n}$ enterprises and $E\left(A^{\max }\right)=n h / n+1 \frac{\mathrm{nh}}{\mathrm{n}+1} \frac{\mathrm{nh}}{\mathrm{n}+1}$, so that $E\left(A^{\max }\right)=h / 2$, when $\mathrm{n}=1 ; E\left(A^{\max }\right) \rightarrow h$, when $n \rightarrow \infty$. Therefore, probability and expectation for enterprise (i) to imitate other products are as follows:

$$
\begin{aligned}
& \operatorname{prob}\left(A_{i}<\theta A^{\max }\right)=\frac{\theta n}{n+1} \\
& E\left(A_{i} / A_{i}<\theta A^{\mathrm{max}}\right)=h \frac{\theta n}{n+1}
\end{aligned}
$$

In the same way, probability and expectation for enterprise (i) to manufacture its own products are as follows:

$$
\begin{aligned}
& \operatorname{prob}\left(A_{i} \geq \theta A^{\max }\right)=1-\frac{\theta n}{n+1} \\
& E\left(A_{i} / A_{i} \geq \theta A^{\max }\right)=\frac{1}{2} h \frac{\theta n}{n+1}
\end{aligned}
$$

Thus, expectation of Export Department's technical parameter $\mathrm{A}$ is:

$$
E(A)=\frac{1}{2} h\left[1+\left(\frac{\theta n}{n+1}\right)^{2}\right]
$$

Substituting Formula (6) into Formula (1), we can gain productivity level of a country's manufacturing enterprises as follows:

$$
\frac{E(Y)}{L}=\frac{1}{2} h\left[1+\left(\frac{\theta n}{n+1}\right)^{2}\left(\frac{K}{L}\right)\left(\frac{N}{L}\right)\right]
$$

Thereinto,

$$
\begin{aligned}
V S I_{i}= & \frac{\mu A^{M D}\left(1-A^{M D}\right)^{-1}\left(1-X^{P}\right)}{X} \\
& \frac{+\mu\left[A^{M D}\left(1-A^{D D}\right)^{-1} A^{D P}+A^{M P}\right] X^{P}}{X}
\end{aligned}
$$


Finally, the function mechanism for producer services to upgrade value chain was analyzed. Thus it can be seen from Formula (7) whether rising of enterprises' productivity level can promote its position in global value chain, mainly depends on the number of enterprises, per capita capital, material capital, natural resources, internal knowledge, external knowledge, institutional system, innovation policy, producer services with the property of intermediate inputs and producer service networks engaged in new products' development and cost discovery. Therefore, producer service network can affect the position of a country or region in global value chain. In this paper, the author thinks that the influence of network of producer services on upgrade value chain can be mainly in the following four fields:

(1) Spatial Effects of Innovative Network: Innovative network, composed of enterprises, universities, scientific research institutions, government, financing institutions and users, is an important support of enterprises in upgrade value chain. One scholar thought: "the abilities of enterprises in integrating, building and relocating their internal and external resources are sources of enterprises' competitive advantages. Such producer services as information technology, communication, transportation, logistics, and science and technology service industry can build cross-regional spatial networks and promote deep integration of different regions in industry-university-research cooperation. In addition, open innovation emphasizes acquiring dynamic information. Innovative spatial network can form flexible innovative organization and enhance enterprise's competitiveness through timely response and agile manufacturing.

(2) Spatial Effects of Financial Network: Financial supports are important guarantees of upgrade value chain. How to solve assignment problems of capital elements in different spaces is one of the key issues to be solved by modern financial network. Effects of information and internet technology on financial capital allocation have gone deep into credit system, financing channels, and risk control, and such emerging business modes as mobile payment, P2P credit and loan, crowd funding, and Bitcoin have also been observed. Such internet financial services have expanded the range of financial industries, met enterprises' demands in financing through integrating resources in a wider spatial scale, and promoted upgrade value chain of enterprises.

(3) Spatial effects of Logistics Network: The process of upgrading value chain is a complex process of system's division, from internal integration production by Koase in 1937, to decentralized production within the enterprise and to external module production. Finally, it connects such modules depending on producer services, so that logistics producer services play a more important role. Such producer services as communication and transportation, storage, postal service, information transmission, software and information technology services are significant elements for the formation of logistics network. With rapid development of information and communication technology and e-commerce, logistics network can realize products' space-time compression to the maximum limit, to guarantee timely connection of commodity supply and demand in the circulation area and to realize upgrade value chain.
(4) Spatial Effects of Marketing Network: Marketing network is a mutually beneficial economic relationship between enterprises and customers, suppliers, distributors, dealers, agents, shareholders, investors and analyzers [17], which is mainly formed by such producer service networks by consultation, utilizing logistics, advertisement, exhibition, marketing, after-sales services as well as information, science and technology services. The construction of marketing network plays an important role in collecting market information, expanding sales channels, and building international-brand products and professional markets. On one hand, marketing network can determine supply and demand and save transaction costs; on the other hand, marketing network adjusts a product's positioning continuously through spatial linkage among enterprises, so as to meet marketing demands and to promote its position in global value chain.

\section{ECONOMETRIC MODEL AND VARIABLE SELECTION}

\subsection{Model Specification}

This paper studied spatial network effects of producer services on value chain with the use of spatial econometric model. Anselin [18] studied spatial econometric model systematically and brought spatial factors, which were ignored in typical econometric model. Basic spatial econometric models include spatial lag model (SLM model) and spatial error model (SEM model). Referring to the study of Cohen [19], this paper set up spatial lag model (SLM model) as follows:

$$
y_{i t}=\beta_{0}+\beta_{1} Z_{i t}+\beta_{2} X_{i t}+\rho \sum_{j} W_{i j} X_{j t}+\varepsilon_{i t}
$$

Where, $y_{i t}$ is an explained variable, indicating domestic export technical complexity in the province, namely the position of the province in global value chain; $Z_{i t}$ is various control variables; $X_{i t}$ is an explanatory variable, indicating added value of the province's producer services; $X_{j t}$ is the added value of adjacent provinces' producer services; $W_{i j}$ is a spatial weight matrix showing the effects of adjacent provinces' producer services on the province's value chain reflected as coefficient $\rho, \varepsilon_{i t}$ is the error term, and $\varepsilon_{\mathrm{it}} \sim \mathrm{N}\left[0, \sigma^{2}\right]$. Thus it can be seen from Formula (8) that producer services of province (j) can "superimpose" effects to value chain of province (i) by affecting value chain change of the province, and namely coefficient $\rho$ comprehensively expresses influences of explained variables among adjacent provinces.

When error terms have spatial correlations, it is necessary to set the model as a spatial error model (SEM):

$$
y_{i t}=\beta_{0}+\beta_{1} Z_{i t}+\beta_{2} X_{i t}+\beta_{3} X_{j t}+\rho \sum_{j} W_{i j} \varepsilon_{i t}+\mu_{i t}
$$

Where, $\mu_{i t}$ is an error and $\mu_{i t} \sim N\left[0, \sigma^{2}\right]$.

In this paper, the author comprehensively measures the coupling effects of value chain in various regions of China, direct enhancements of producer services on value chain, and 
spatial network effects. Spatial weight matrix $W$ includes contiguity based spatial weight matrix, distance based spatial weight matrix, and social economy spatial weight matrix.

\section{(1) Contiguity Based Spatial Weight Matrix}

Geographical distribution in all the links of value chain possesses "spatial logic" and change in value chain is linked with the whole chain in the whole space. For neighboring relations of all provinces, all links of value chain are arranged in adjacent provinces. Therefore, we set geographical distance spatial weight matrix depending on whether spaces are adjacent or not. The adjacent domains are endowed with "l", while other domains are endowed with " 0 " [20]. Definition of the weight matrix is as follows:

$W_{i j}= \begin{cases}1 & \text { When } i \text { and } j \text { are adjacent } \\ 0 & \text { When } i \text { and } j \text { are not adjacent }\end{cases}$

\section{(2) Distance Based Spatial Weight Matrix}

Of course, neighboring relations cannot reflect the spatial correlation of value chain activities completely. For example, Beijing only borders upon Tianjin and Hebei, but we can not exclude links of Beijing to other provinces. Therefore, we structure geographical distance in spatial weight matrix to consider relations of farther space units. $W_{i j}$ is a matrix element of row No. $i$ and line No. $j$ and row and line correspond to spatial units. $d_{i j}$ is the geographical distance between spatial unit $i$ and spatial unit $j$, which is expressed with straightline Euclidean distance between provinces and provincial capitals. $d_{i j}$ indicates the distance between the capital of province $i$ and province $j$, whose definition is as follows:

$$
W_{i j}= \begin{cases}\frac{1}{d_{i j}} & \text { when } i=j \\ 0 & \text { when } i \neq j\end{cases}
$$

\section{(3) Social Economy Based Spatial Weight Matrix}

Social economy spatial weight matrix mainly investigates two economic areas with similar development degree. In this paper, economic spatial weight matrix was set according to the decreasing count $\mathrm{s}$ of the two provinces' average income level difference. The smaller the difference in the income of the two provinces, the closer their economic level. Therefore, for the larger weight, and on the contrary, smaller weight [21], the definition is as follows:

$$
W_{i j}= \begin{cases}\frac{1}{\left|Y_{i}-Y_{j}\right|} & \text { when } i=j \\ 0 & \text { when } i \neq j\end{cases}
$$

\subsection{Index Selection and Variable Declaration}

\subsubsection{Explained Variable: Status of Different Regions in Global Value Chain (V-Chain)}

Export products' technical complexity of a country or region can reflect the position of the country or region in global value chain [22]. Rodrik [22] conducted advanced re- search on export products' technical complexity. On this basis, domestic and overseas scholars conducted a research on export commodities' technical complexity [23-25]. Most scholars pointed out that "at the time of measuring the complexity of export technology, it is necessary for China, particularly, to import a mass of intermediate input products when exporting products. It may cause statistical illusion of overstating export products' technical complexity if the values of intermediate input products are not removed" [25] In view of this, on the basis of the model of Hausmann [16], the author used vertical specialization level method with the country's input-output table referring to Koopman. Measure export products' domestic technical complexity of all provinces through eliminating import intermediate inputs' direct and indirect consumption of export products: firstly, considering different input proportion of general trade and processing trade in import intermediate products, the author divides the input-output table into Input-output Table of General Trade and Input-output Table of Processing Trade, to calculate export consumption of all provinces in China in industry (i)

$V S I_{i}=\frac{\mu A^{M D}\left(1-A^{M D}\right)^{-1}\left(1-X^{P}\right)+\mu\left[A^{M D}\left(1-A^{D D}\right)^{-1} A^{D P}+A^{M P}\right] X^{P}}{X}$.

Here,$\mu$ indicates $1 \times n$ dimensional vector, $\mathrm{X}$ indicates regional export scale, XP indicates processing trade export, $1-X^{P}$ indicates general trade export, AMD indicates consumption coefficient matrix for import intermediate input products to produce domestic sales products and general export commodities. ADD indicates consumption coefficient matrix for domestic intermediate input products to produce domestic sales products and general export commodities; ADP indicates consumption coefficient matrix for domestic intermediate input products to produce export commodities; AMP indicates consumption coefficient matrix for import intermediate input products to produce processing trade export products. Secondly, the paper calculates export technological complexity of industries (i) in various provinces of China,

$\operatorname{PRODY}_{i}=\sum_{c} \frac{S_{i c}}{\sum_{c} S_{i c}} Y_{c}$.

$S_{i c}$ indicates export commodity proportion of industry (i) in region (c) and $Y_{c}$ indicates per capita GDP in region (c), namely export technology complexity of industry (i) as per capita GDP and weighing of different regions. Finally, it is necessary to compute domestic technology complexity of export products in various regions of China,

$$
\operatorname{EXPRODY}_{c}=\sum_{i} \frac{\left(1-V S I_{i}\right) S_{i c}}{\sum_{i}\left(1-V S I_{i}\right) \sum_{c} S_{i c}} \times\left(1-V S I_{i}\right) P R O D Y_{i},
$$

which reflects the position of all provinces' export technology complexity in global value chain. Considering that $95 \%$ of Chinese export products come from manufactured goods, the author did not consider monopolistic gas production and supply industry, electric steam hot water production and supply industry, tap water production and supply industry. Referring to "standard classification and classification stand- 
ard conversion" principle of one scholar, the author matched GB coding in Chinese input-output Table and trading data HS coding in customs database with the use of industry code, and summarized and subdivided 20 manufacturing industries. As for selection of input-output table, in view that the latest input-output table in China has only been updated upto the year 2007 so far, computing interval of this paper is from 2002 to 2010. The author selected two input-output basic tables of 2002 and 2007 and two input-output extension table of 2005 and 2010. Only the input-output table of 2007 listed with import and export adjustment data. In this paper, vertical specialization degree of all industries in inputoutput table of other years was calculated according to the proportion of processing equipment export to all trade exports in the input-output table of 2007. Furthermore, for years without input-output tables, average growth rate of vertical specialization division can be calculated approximately. Trading data of different regions and per capita GDP of all provinces obtained from China Customs database, DRCNET, and China's economic and social development statistical database.

\subsubsection{Core Explanatory Variable: Producer Services (P- services)}

In accordance with National Industries Classification (GB/4754-2011), producer services mainly include communication, transportation, warehousing, post and telecommunication industry; wholesale and retail trade; information transmission, software, and information technology service industry; financial industry; leasing and commercial service industry; scientific research and technical support service industry; water conservancy, environment, and public facility management industry; education; hygiene. Based on data availability, added value of producer services over the years is the added value of the tertiary industry after having dealt with the added value of accommodation and catering service, culture industry, real estate and other services. Data was obtained from Statistical Yearbook of the Tertiary Industry in China over the years and China's economic and social development statistical database.

\subsubsection{Control Variables}

(1) Natural Endowment of Human Capitals (Personnel Number of Scientific and Technological Activities): From factor endowment theory, we know that countries with rich endowment of human capitals possess comparative advantages in human capital-intensive products. At the same time, higher human capital level can reduce workers' learning time, enhance technology adoption speed, and contributes to deepening labor division, improving production efficiency [26], and promoting export products' technical complexity. Data was obtained from Statistical Yearbook of the Tertiary Industry in China over the years and China's economic and social development statistical database.

(2) Infrastructure [Highway Mileage (Kilometer)/Million People]: Convenient and fast public infrastructures can save inventory for enterprises and are good for enterprises to adjust production factors timely and effectively, so as to reduce the adjustment cost [12]. In addition, completed infrastructural facilities play a particularly important role in the export of products with high complexity, so as to raise their position in global value chain. Data was obtained from statistical yearbook of all provinces over the years and China's economic and social development statistical database.

(3) Open [Total Export-Import Volume (RMB 0.1 Billion/GDP): After participating in international trade, enterprises can promote their own technological level through introducing technologies or learning exchange. Therefore, opening degree can promote a region's position in global value chain. Data for this was obtained from statistical yearbook of all provinces over the years and China's economic and social development statistical database.

(4) Institutional Factors (Marketing Indexes): Institutional conditions are the key factors affecting technological innovation. Countries with better institutional conditions have better weight conditions, which is in favor of invention and innovation and promoting export products' technical complexity. Therefore, institutional conditions can also promote regions' position in global value chain. Data for this was obtained from Marketing Indexes in Various Regions of China compiled by Fan Gang and Wang Xiaolu.

(5) R\&D Stock [Internal Spending of R\&D Expenditures (RMB 10, 000)]: Innovation is a driving force for rising global value and R\&D expenditures are closely related to whether innovation can succeed or not. Data for this was obtained from statistical yearbook of all provinces over the years and China's economic and social development statistical database.

\section{RESULT ANALYSIS}

\subsection{Correlation Inspection for Value Chain of Various Regions of China in Global Extent}

This study considered the first difference of domestic technical complexity of various provinces as position change conditions in global value chain to measure whether regional value chain change has a global space correlation or not with the use of Moran's I index. Value range of Moran's I index is $-1 \leq \mathrm{I} \leq 1 ; \mathrm{I}<0$ indicates negative correlation, $\mathrm{I}>0$ indicates positive correlation, while $\mathrm{I}=0$ indicates noncorrelation. As for Moran's I index, it was assessed whether $\mathrm{n}$ regions have spatial autocorrelation or not with the use of standard statistics $Z$. For example, $Z>1.96$ indicates positive correlation, and $\mathrm{P}$ is a significance level. Results are shown in Table 1: Global Moran's I index from 2002 to 2010 was positive. All $\mathrm{Z}$ indexes were larger than 1.96 and went through significance testing $(\mathrm{p}<0.01)$, which indicated spatial correlation in the value chain change.

Table 1. Global Moran's I Index and Significance Testing.

\begin{tabular}{|c|c|c|c|c|c|c|c|}
\hline Year & $\begin{array}{c}\text { Moran } \\
\text { I i n- } \\
\text { dex }\end{array}$ & $\begin{array}{c}\text { Z val - } \\
\text { ue }\end{array}$ & $\begin{array}{l}\text { P val - } \\
\text { ue }\end{array}$ & Year & $\begin{array}{c}\text { Mran } \\
\text { I n- } \\
\text { dex }\end{array}$ & $\begin{array}{c}\text { Z val - } \\
\text { ue }\end{array}$ & Pal - \\
ue
\end{tabular}




\subsection{Correlation Inspection for Value Chain of Various Regions of China in Partial Space}

Moran scatter diagram of value chain change was drawn to inspect whether value chain for various regions of China shows correlation in partial space. Moran scatter diagram was drawn by Geoda software to find out the corresponding provinces in the table or map by clicking every point in the diagram. As can be observed from Moran scatter diagram (see Figs. (1) and (2)), value chain change of various regions showed strong spatial correlation in partial space.

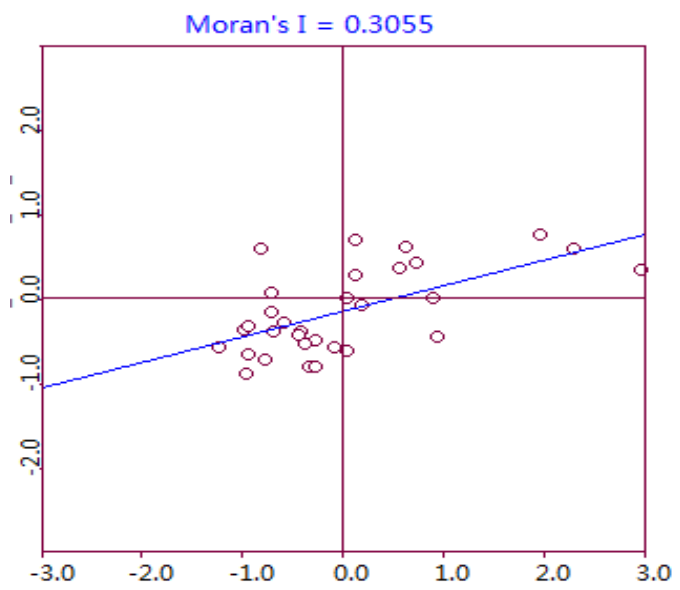

Fig. (1). Mran scat ter di agram in 2002.

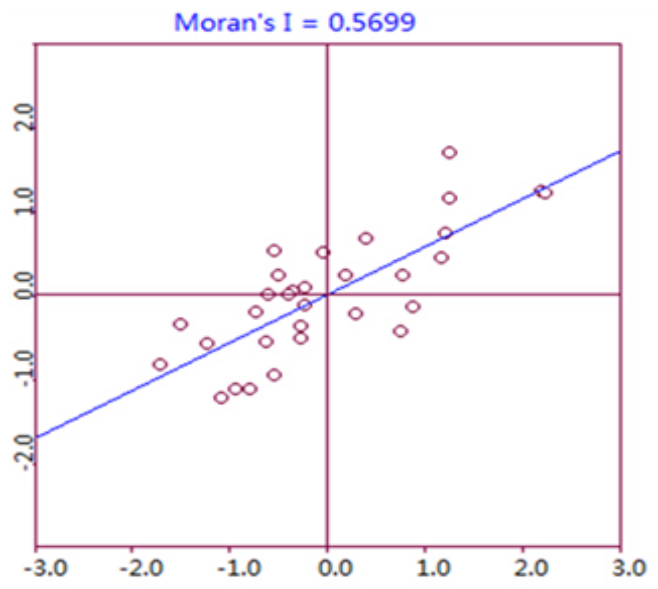

Fi g. (2). Mran scatter diagramin 2010.

In Moran scatter diagram of value chain change of various regions of China in 2002, seven provinces and regions such as Beijing, Shanghai, Tianjin, Liaoning, Jiangsu, Zhejiang, Shandong, and Guangdong are in the first quadrant, as high-high (HH) type (dark color parts in Fig. (3)). It indicates that the pace of value chain of such provinces is the fastest and they form a kind of mutually strengthening relation in space; however, other seven provinces such as Sinkiang, Tibet, Qinghai, Gansu, Yunnan, Guizhou, and Guangxi are in the fourth quadrant, as low-low (LL) type (light color parts in Fig. (3)). It indicates that the pace of value chain of such provinces is the lowest and they form a kind of inter-inhibitive relation in space.
By 2010, the situation has changed. The following nine provinces such as Beijing, Tianjin, Hebei, Shanghai, Jiangsu, Zhejiang, Anhui, Guangdong, and Hunan are in the first quadrant, as high-high (HH) type (dark color parts in Fig. (4)). It indicates that speed of value chain of such provinces is the fastest and they form a kind of mutually strengthening relation in space; however, the following seven provinces such as Sinkiang, Tibet, Qinghai, Gansu, Yunnan, Guizhou, and Guangxi are still in the fourth quadrant, as low-low (LL) type (light color parts in Fig. (4)), which indicates that value chain change rule of such provinces has not changed. Furthermore, mutually strengthening spatial correlation of value chain created a city-core region correlation, with big cities covering areas of producer services.

\subsection{Regression Analysis on Spatial Econometrics}

In view of spatial correlation in value chain change in China, only time dimension was considered, thus ignoring correlation and heterogeneity of spatial dimension. Therefore, in this paper, the author brought spatial correlation to analytical framework of producer services and value chain change in various regions of China.

For easy comparison, we also conducted regression of common panel data. In order to judge panel data model, it is necessary to conduct Hausman inspection, and the results support fixed-effect model. Actually, when samples are taken from population at random, it is suitable to choose random-effect model. However, when regression analysis is limited to some specific individuals, it is necessary to choose fixed-effect model [27]. As for value chain dynamic analysis divided as per Chinese provincial level, fixed-effect model was obviously a better choice. Furthermore, Geoda software can only dispose cross-section data. We divide data into two time quanta (2002-2006, 2007-2010) and conduct regression of spatial econometrics after averaging. We could not judge spatial correlation among model variables, therefore we listed all model results in Tables 2, 3 and 4. Observed from the whole model selection, various model results do not have oversized differences in positive or negative of coefficient, thus verifying model applicability to some extent.

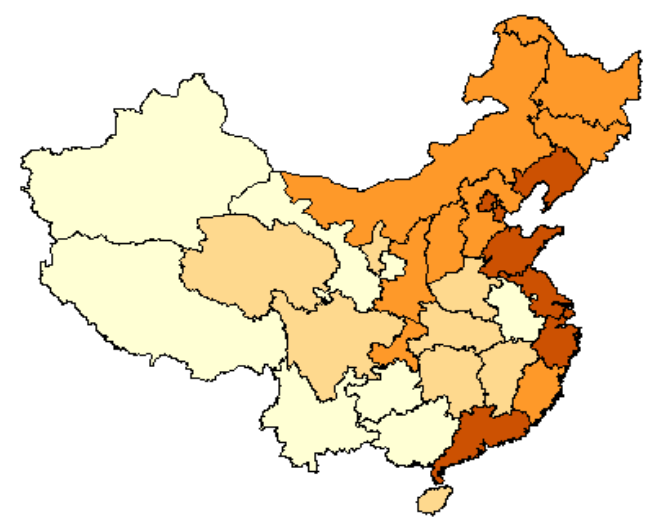

Fig. (3). Spatial Relationship of Value Chain Change in 2002. 


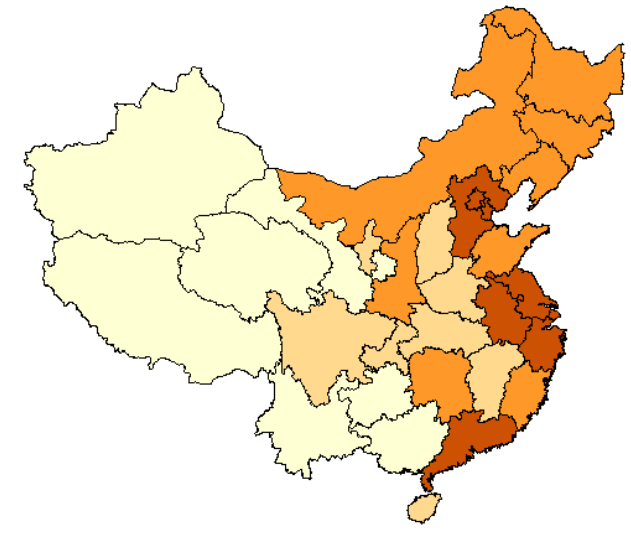

Fig. (4). Spatial Relationship of Value Chain Change in 2010.

In positivism model results, influence of coefficient of opening to the outside world on the value chain is negative and all other coefficients of model are positive, with high significance. As for spatial lag $W \times P$ and $W \times \mathcal{E}$ coefficient, the spatial lag coefficient in SLM and SEM model from 2002 to 2006 is not significant, which indicates that they are close. Producer services among provinces are not very obvious to upgrade the value chain in various regions of China.
However, spatial lag coefficient in SLM and SEM model from 2007 to 2010 was observed to be extremely remarkable, which indicates that producer services have positive effects on element integration and market development of closely connected provinces, thus promoting upgrade value chain in various regions of China. It supports the above hypothesis that producer services have spatial network effects. On the whole, producer services have obvious promotion effects on value chain change in various regions of China and development of producer services in adjacent domains can significantly promote local value chain change. The author was of the view that adjacent provinces tend to conduct regional economic cooperation, while site selection of all links of value chain tends to adjacent provinces.

Model fitting and inspection results show that variables set in the above model can explain the major value chain change when adjustment $\mathrm{R}^{2}$ value is above 0.8 . F-statistics is highly significant, which indicates that coefficient can not be 0 in the meantime. Besides goodness-of-fit of $\mathrm{R}^{2}$, Loglikelihood, AIC, and SC are frequently-used norms. The larger the Log-likelihood is, the smaller the values of AIC and SC, and the better the model fitting effect . By comparing Classical Linear Regression Model estimated by OLS, SLM and SEM, AIC of SLM was much smaller than the AIC of OLS model, which indicated that SLM remarkably improved than the OLS model.

Table 2. Estimated Results for Contiguity Based Spatial Weight Matrix.

\begin{tabular}{|c|c|c|c|c|c|c|}
\hline \multirow{2}{*}{ Explanatory Variable } & \multicolumn{2}{|c|}{ Ordi nary Panel (OLS) } & \multicolumn{2}{|c|}{ M Estimtion of SLMMdel } & \multicolumn{2}{|c|}{ M Estimtion of SEMMdel } \\
\hline & 2002-2006 & 2007-2010 & 2002-2006 & 2007-2010 & 2002-2006 & 2007-2010 \\
\hline P-services & $\begin{array}{c}0.42 * * * \\
(4.52)\end{array}$ & $\begin{array}{c}0.34 * * * \\
(2.94)\end{array}$ & $\begin{array}{l}0.57 * * * \\
(3.17)\end{array}$ & $\begin{array}{l}0.22 * * * \\
(5.33)\end{array}$ & $\begin{array}{l}0.68 * * * \\
(4.81)\end{array}$ & $\begin{array}{l}0.37 * * * \\
(2.99)\end{array}$ \\
\hline $\mathrm{R} \& \mathrm{D}$ & $\begin{array}{c}0.39 * * * \\
(3.77)\end{array}$ & $\begin{array}{c}0.17^{* * *} \\
(4.12)\end{array}$ & $\begin{array}{c}0.13^{* * *} \\
(4.78)-0.13^{* * *}\end{array}$ & $\begin{array}{l}0.58 * * * \\
(5.43)\end{array}$ & $\begin{array}{l}0.44 * * * \\
(3.53)\end{array}$ & $\begin{array}{l}0.21 * * * \\
(2.93)\end{array}$ \\
\hline Open & $\begin{array}{l}0.044 \\
(0.89)\end{array}$ & $\begin{array}{l}-0.005 \\
(0.71)\end{array}$ & $\begin{array}{c}(7.21) \\
0.54 * * *\end{array}$ & $\begin{array}{c}-0.0034 \\
(0.96)\end{array}$ & $\begin{array}{l}0.16^{* * *} \\
(4.20)\end{array}$ & $\begin{array}{c}-0.0037 \\
(1.01)\end{array}$ \\
\hline Hunan & $\begin{array}{c}0.27 * * * \\
(7.08)\end{array}$ & $\begin{array}{c}0.013^{* * *} \\
(3.64)\end{array}$ & $\begin{array}{c}(5.13) \\
0.0071^{* * *}\end{array}$ & $\begin{array}{c}0.097 * * \\
(2.67)\end{array}$ & $\begin{array}{c}0.36^{* * *} \\
(9.61)\end{array}$ & $\begin{array}{l}0.056^{*} \\
(1.68)\end{array}$ \\
\hline Infra & $\begin{array}{c}0.036^{* * *} \\
(3.11)\end{array}$ & $\begin{array}{c}0.054 * * * \\
(5.32)\end{array}$ & $\begin{array}{c}(10.43) \\
0.018^{* * *}\end{array}$ & $\begin{array}{c}0.043^{* * *} \\
(3.85)\end{array}$ & $\begin{array}{c}0.046^{* * *} \\
(3.75)\end{array}$ & $\begin{array}{c}0.006^{* * *} \\
(6.41)\end{array}$ \\
\hline Inst it ut i on & $\begin{array}{c}0.063^{* * *} \\
(3.48)\end{array}$ & $\begin{array}{l}0.027 \\
(1.87)\end{array}$ & $\begin{array}{c}(4.88) \\
0.15\end{array}$ & $\begin{array}{c}0.056^{* * *} \\
(6.87)\end{array}$ & $\begin{array}{c}0.042 * * * \\
(3.75)\end{array}$ & $\begin{array}{l}0.052 \\
(1.75)\end{array}$ \\
\hline$W \times P / W \times \varepsilon$ & & & $\begin{array}{c}(1.34) \\
0.095^{* * *}\end{array}$ & $\begin{array}{c}0.27 * * * \\
(3.99)\end{array}$ & $\begin{array}{c}0.36 \\
(0.82)\end{array}$ & $\begin{array}{l}0.16^{* * *} \\
(5.16)\end{array}$ \\
\hline Const ant & $\begin{array}{c}0.032 * * * \\
(7.38)\end{array}$ & $\begin{array}{c}0.016^{* * *} \\
(5.29)\end{array}$ & $(4.43)$ & $\begin{array}{c}0.007^{* * *} \\
(2.79)\end{array}$ & $\begin{array}{c}0.092^{* * *} \\
(5.90)\end{array}$ & $\begin{array}{l}0.08 * * * \\
(3.78)\end{array}$ \\
\hline F-St at ist i cs & 146 & 217 & 118 & 98 & 99 & 114 \\
\hline Log-1 i kel i hood & -80 & -52 & -56 & -63 & -67 & -46 \\
\hline $\mathrm{AlC}$ & 677 & 973 & 734 & 605 & 415 & 881 \\
\hline $\mathrm{SC}$ & 44 & 56 & 36 & 32 & 35 & 29 \\
\hline Adj ust ed $\mathrm{R}^{2}$ & 0.78 & 0.79 & 0.79 & 0.82 & 0.91 & 0.83 \\
\hline Observed-val ue & 31 & 31 & 31 & 31 & 31 & 31 \\
\hline
\end{tabular}

Notes: contents inside ( ) are statistics of $\mathrm{t}$; symbols $* * *, * *$, and $*$ indicate that the variable passes $1 \%, 5 \%$, and $10 \%$ of significance level. 
Table 3. Estimated Results for Distance Based Spatial Weight Matrix.

\begin{tabular}{|c|c|c|c|c|c|c|}
\hline \multirow{2}{*}{ Explanatory Variable } & \multicolumn{2}{|c|}{ Ordi nary Panel (OLS) } & \multicolumn{2}{|c|}{ M Esti mation of SLM Mdel } & \multicolumn{2}{|c|}{ ML Esti mation of SEMMdel } \\
\hline & 2002-2006 & 2007-2010 & $2002-2006$ & 2007-2010 & 2002-2006 & 2007-2010 \\
\hline P-services & $\begin{array}{c}0.42 * * * \\
(4.52)\end{array}$ & $\begin{array}{l}0.34 * * * \\
(2.94)\end{array}$ & $\begin{array}{c}0.44 * * * \\
(4.16)\end{array}$ & $\begin{array}{l}0.32 * * * \\
(6.13)\end{array}$ & $\begin{array}{l}0.51 * * * \\
(3.41)\end{array}$ & $\begin{array}{l}0.27 * * * \\
(5.09)\end{array}$ \\
\hline $\mathrm{R} \& \mathrm{D}$ & $\begin{array}{l}0.39 * * * \\
(3.77)\end{array}$ & $\begin{array}{l}0.17 * * * \\
(4.12)\end{array}$ & $\begin{array}{c}0.26^{* * *} \\
(5.71)-0.023 * * *\end{array}$ & $\begin{array}{l}0.58 * * * \\
(3.46)\end{array}$ & $\begin{array}{l}0.34 * * * \\
(4.56)\end{array}$ & $\begin{array}{l}0.67 * * * \\
(4.93)\end{array}$ \\
\hline Open & $\begin{array}{r}0.044 \\
(0.89)\end{array}$ & $\begin{array}{l}-0.005 \\
(0.71)\end{array}$ & $\begin{array}{c}(4.22) \\
0.33 * * *\end{array}$ & $\begin{array}{c}-0.0034 \\
(0.36)\end{array}$ & $\begin{array}{l}0.15^{* *} \\
(2.12)\end{array}$ & $\begin{array}{l}-0.026 \\
(0.09)\end{array}$ \\
\hline Human & $\begin{array}{l}0.27^{* * *} \\
(7.08)\end{array}$ & $\begin{array}{l}0.013 * * * \\
(3.64)\end{array}$ & $\begin{array}{c}(6.13) \\
0.023 * * *\end{array}$ & $\begin{array}{l}0.076^{* *} \\
(1.97)\end{array}$ & $\begin{array}{l}0.36^{* *} \\
(9.61)\end{array}$ & $\begin{array}{c}0.15 \\
(1.66)\end{array}$ \\
\hline Infra & $\begin{array}{c}0.036^{* * *} \\
(3.11)\end{array}$ & $\begin{array}{c}0.054 * * * \\
(5.32)\end{array}$ & $\begin{array}{c}(18.11) \\
0.058^{* * *}\end{array}$ & $\begin{array}{c}0.038 * * * \\
(7.83)\end{array}$ & $\begin{array}{c}0.076^{* * *} \\
(2.79)\end{array}$ & $\begin{array}{c}0.043 * * * \\
(3.48)\end{array}$ \\
\hline Inst it ut i on & $\begin{array}{c}0.063^{* * *} \\
(3.48)\end{array}$ & $\begin{array}{r}0.027 \\
(1.87)\end{array}$ & $\begin{array}{l}(5.52) \\
0.22 * * *\end{array}$ & $\begin{array}{l}0.056^{*} \\
(1.87)\end{array}$ & $\begin{array}{l}0.049 * * \\
(2.75)\end{array}$ & $\begin{array}{l}0.043 \\
(1.55)\end{array}$ \\
\hline$W \times P / W \times \varepsilon$ & & & $\begin{array}{c}(7.34) \\
0.006^{* * *}\end{array}$ & $\begin{array}{l}0.16^{* * *} \\
(4.95)\end{array}$ & $\begin{array}{l}0.37 * * * \\
(4.99)\end{array}$ & $\begin{array}{l}0.28 * * \\
(7.12)\end{array}$ \\
\hline Const ant & $\begin{array}{c}0.032 * * * \\
(7.38)\end{array}$ & $\begin{array}{l}0.016^{* * *} \\
(5.29)\end{array}$ & $(4.47)$ & $\begin{array}{c}0.053^{* * *} \\
(4.72)\end{array}$ & $\begin{array}{l}0.066^{* * * *} \\
(3.94)\end{array}$ & $\begin{array}{c}0.076^{* * *} \\
(4.33)\end{array}$ \\
\hline F-statistics & 146 & 217 & 118 & 98 & 99 & 114 \\
\hline Log-1 i kel i hood & -80 & -52 & -36 & -73 & -54 & -48 \\
\hline $\mathrm{AIC}$ & 677 & 973 & 221 & 456 & 478 & 362 \\
\hline $\mathrm{SC}$ & 44 & 56 & 56 & 42 & 33 & 46 \\
\hline Adj ust ed $\mathrm{R}^{2}$ & 0.78 & 0.79 & 0.82 & 0.81 & 0.84 & 0.83 \\
\hline Observed - val ue & 31 & 31 & 31 & 31 & 31 & 31 \\
\hline
\end{tabular}

Notes: contents inside ( ) are statistics of $\mathrm{t}$; symbols $* * *, * *$, and * indicate that the variable passes $1 \%, 5 \%$, and $10 \%$ of significance level.

Comparing regression coefficient of contiguity-based spatial weight matrix and distance-based spatial weight matrix, we found that the value chain in various regions of China have a stronger spatial correlation with geographical distance. Coefficients of SLM model and SEM model were observed to be significant, whose spatial correlation coefficients were $0.22,0.16,0.37$, and 0.28 , indicating that economic activities can be expanded with geographical distance rather than limited to adjacent provinces. Actually, spatial distribution of all links in value chain exists in regions not adjacent in terms of geographical position. Therefore, compared with contiguity based spatial weight matrix, distance based spatial weight matrix can reflect more objective facts.

For value chain's spatial network effects, producer services were more influential in spatial weight matrix of geographical distance. Producer services had positive effects on rational distribution of value chain, suggesting that such spatial connection may fail gradually with continuous extension of geographical distance.

Weight matrix model of economic characteristics reflected spatial network effects of producer services on upgrade value chain and spatial correlation coefficient was observed to be larger than geographical distance model. Namely, the closer the geographical distance degree, the stronger the value chain's spatial correlation effect. However, the larger the economic development difference, the weaker the connected effect of value chain, indicating that progress of Chinese enterprises does not depend on the integration of regional resources but tends to develop market in regions with similar development degree.

Proximity space and geographical distance tend to embody supply chain network of value chain, namely coordination between upstream and downstream enterprises. However, spatial weight matrix of economic characteristics embodies more innovative network and marketing network. In other words, economic development level embodies not only market effect but also scientific research ability and the level of technological and industrial innovation. Model regression for spatial weight matrix of economic characteristics indicates that the communication of producer services is even greater in regions with higher economic development level. Chinese enterprises tend to integrate professional resources rather than building supporting relations among upstream and downstream enterprises.

\section{CONCLUSION AND POLICY SUGGESTIONS}

In this paper, the author analyzed the functional mechanism for producer services to upgrade value chain based on 
Table 4. Estimated Results for Social Economy Based Spatial Weight Matrix.

\begin{tabular}{|c|c|c|c|c|c|c|}
\hline \multirow{2}{*}{ Explanatory Variable } & \multicolumn{2}{|c|}{ Ordi nary Panel (OLS) } & \multicolumn{2}{|c|}{ M Esti mation of SLM model } & \multicolumn{2}{|c|}{ M Estimtion of SEMMdel } \\
\hline & 2002-2006 & 2007-2010 & 2002-2006 & 2007-2010 & 2002-2006 & 2007-2010 \\
\hline P-services & $\begin{array}{c}0.42 * * * \\
(4.52)\end{array}$ & $\begin{array}{c}0.34 * * * \\
(2.94)\end{array}$ & $\begin{array}{c}0.45^{* * *} \\
(3.17)\end{array}$ & $\begin{array}{l}0.37 * * * \\
(7.16)\end{array}$ & $\begin{array}{l}0.56^{* * *} \\
(4.45)\end{array}$ & $\begin{array}{l}0.34 * * * \\
(6.08)\end{array}$ \\
\hline $\mathrm{R} \& \mathrm{D}$ & $\begin{array}{l}0.39 * * * \\
(3.77)\end{array}$ & $\begin{array}{c}0.17 * * * \\
(4.12)\end{array}$ & $\begin{array}{c}0.28^{* * *} \\
(3.78)-0.093^{* *}\end{array}$ & $\begin{array}{l}0.48^{* * * *} \\
(5.32)\end{array}$ & $\begin{array}{c}0.37^{* * *} \\
(5.51)\end{array}$ & $\begin{array}{l}0.69 * * * \\
(5.96)\end{array}$ \\
\hline Open & $\begin{array}{l}0.044 \\
(0.89)\end{array}$ & $\begin{array}{l}-0.005 \\
(0.71)\end{array}$ & $\begin{array}{c}(3.22) \\
0.06^{* * *}\end{array}$ & $\begin{array}{c}-0.0064 \\
(0.36)\end{array}$ & $\begin{array}{l}0.015^{* *} \\
(2.21)\end{array}$ & $\begin{array}{l}-0.061 \\
(0.00)\end{array}$ \\
\hline Human & $\begin{array}{l}0.27 * * * \\
(7.08)\end{array}$ & $\begin{array}{c}0.013 * * * \\
(3.64)\end{array}$ & $\begin{array}{c}(6.13) \\
0.027 * * *\end{array}$ & $\begin{array}{c}0.036^{* *} \\
(1.97)\end{array}$ & $\begin{array}{c}0.16^{* * *} \\
(3.66)\end{array}$ & $\begin{array}{l}0.27 * * * \\
(5.63)\end{array}$ \\
\hline Infra & $\begin{array}{c}0.036^{* * *} \\
(3.11)\end{array}$ & $\begin{array}{c}0.054 * * * \\
(5.32)\end{array}$ & $\begin{array}{c}(7.25) \\
0.058 * * *\end{array}$ & $\begin{array}{c}0.019 * * * \\
(3.84)\end{array}$ & $\begin{array}{c}0.058^{* * *} \\
(2.91)\end{array}$ & $\begin{array}{c}0.045^{* * *} \\
(3.58)\end{array}$ \\
\hline Inst $i t$ ut i on & $\begin{array}{c}0.063^{* * *} \\
(3.48)\end{array}$ & $\begin{array}{l}0.027 \\
(1.87)\end{array}$ & $\begin{array}{c}(5.52) \\
0.59 * * *\end{array}$ & $\begin{array}{l}0.056^{*} \\
(1.87)\end{array}$ & $\begin{array}{l}0.049^{* *} \\
(2.75)\end{array}$ & $\begin{array}{l}0.043 \\
(1.55)\end{array}$ \\
\hline$W \times P / W \times \varepsilon$ & & & $(4.36)$ & $0.47^{* * *}$ & $0.73^{* * *}$ & $0.65^{* *}$ \\
\hline Const ant & $\begin{array}{c}0.032 * * * \\
(7.38)\end{array}$ & $\begin{array}{c}0.016^{* * *} \\
(5.29)\end{array}$ & $\begin{array}{c}0.021 * * * \\
(5.47)\end{array}$ & $\begin{array}{c}(5.91) \\
0.052 * * * \\
(4.74)\end{array}$ & $\begin{array}{c}(3.97) \\
0.026^{* * *} \\
(3.44)\end{array}$ & $\begin{array}{c}(6.18) \\
0.074 * * * \\
(6.36)\end{array}$ \\
\hline F-Stat ist ics & 146 & 217 & 223 & 234 & 351 & 235 \\
\hline Log-1 i kel i hood & -80 & -52 & -76 & -89 & -58 & -99 \\
\hline AI C & 677 & 973 & 221 & 456 & 478 & 362 \\
\hline $\mathrm{SC}$ & 44 & 56 & 78 & 68 & 82 & 68 \\
\hline Adj ust de- $\mathrm{R}^{2}$ & 0.78 & 0.79 & 0.85 & 0.87 & 0.86 & 0.84 \\
\hline Observed-val ue & 31 & 31 & 31 & 31 & 31 & 31 \\
\hline
\end{tabular}

Notes: contents inside ( ) are statistics of $\mathrm{t}$; symbols $* * *,{ }^{* *}$, and $*$ indicate that the variable passes $1 \%, 5 \%$, and $10 \%$ of significance level.

spatial networks, to measure the position of China's provinces in the global value chain with regional domestic Export Sophistication Index and research change rule of provincial value chain. The study also used spatial econometrics model and set a variety of spatial weights matrices, to empirically test the spatial networks' effect formed by the producer services with changes in the position of China's various parts in the global value chain, on the basis of panel data of 31 provinces in China from 2002 to 2010 . By researching, the author found that change in value chain of various regions of China had an obvious spatial correlation, which was strong in the east but weak in the west. Producer services showed obvious effects of spatial network on upgrade global value chain in various regions of China. Such spatial network effects can not only promote the upgrade value chain of local enterprises but also facilitate upgrade value chain of enterprises in other provinces, which verifies the hypothesis that producer services can connect various links of value chain. The estimated results for spatial weight matrix of geographical distance were observed to be more remarkable than that of proximity space and value chain in various regions of China expressed much clearer spatial correlation. Spatial correlation coefficient for weight matrix of economic characteristics was observed to be larger than that for weight matrix of geographical distance, which indicates that the closer the economic development degree, the stronger the spatial correlation effect of value chain in Chinese regions . However, the larger the economic development difference , the weaker the spatial correlation effect of value chain in Chinese regions .

In accordance with the conclusion drawn in this paper, we put forward the following policy suggestions: firstly, there exists spatial correlation in the value chain dynamic of various regions, which reflects spatial and geographical logic of economic operation and is an inevitable embody of market economy rule. Therefore, different regions shall strengthen the synergetic development and perfect matching environment of industrial development through strengthening top-level design, so as to assist rational arrangement in all links of value chain. Secondly, efforts must be made to develop producer services and build spatial networks of value chain division, including innovative network, financial network, logistics network and marketing network, to realize further integration of different regional resources and market integration in a wider scope in order to promote the promotion of Chinese value chain. Thirdly, spatial effect of weight matrix of economic characteristics is larger than that of geographical distance model, which indicates that current Chinese enterprises tend to develop market in regions with similar economic development level, and build "powerful 
club" rather than "combination of the strong and the weak". Integration of regional resources complementarities has considerable usage space. Thus it can be seen that the path for Chinese enterprises to upgrade in value chain is to first cultivate powerful "chain master" and then seek inter-regional associated industries.

\section{CONFLICT OF INTEREST}

The authors confirm that this article content has no conflict of interest.

\section{ACKNOWLEDGEMENTS}

National Planning Office of Philosophy and Social Science (08BJY119), "The thirteenth five-year" major projects by Tianjin development and reform commission (TGPC2014-D0772), The Project on Innovation in Tianjin Universities (Grant No: TD12-5047).

\section{REFERENCES}

[1] A. Thierstein, S. Lüthi, and C. Kruse, "Changing value chain of the Swiss knowledge economy: spatial impact of intra-firm and inter-firm networks within the emerging mega-city region of Northern Switzerland", Regional Studies, vol. 42, no. 8, pp. 1113-1131, 2008.

[2] G. Gereffi, "International trade and industrial upgrading in the apparel commodity chain", Journal of International Economics, vol. 48, no. 1, pp. 37-70, 1999.

[3] C. Cramer, "Can Africa industrialize by processing primary commodities? The case of Mozambican cashew nuts", World Development, vol. 27, no. 7, pp. 1247-1266, 1999.

[4] S. Lall, J. Weiss, and J. Zhang, "The 'sophistication' of exports: a new trade measure", World Development, vol. 34, no. 2, pp. 222237, 2006

[5] H. Y. Tang and H.Q. Zhang, "International intra-product specialization and developing countries' upgrading value chain", Economic Research Journal, no. 9, pp. 81-93, 2009.

[6] B. Qiu, L.F. Ye, and S.Q. Sun, "An empirical study on the impact of GPNs on China's manufacturing industries' upgrading in global value chains: an analysis from the perspective of ESI", China Industrial Economics, no. 1, pp. 57-67, 2012.

[7] W.P. Niu, "Study on generating mechanism and going beyond of international outsourcing trap", China Industrial Economics, no. 5, pp. 109-121, 2012.
[8] M. Y. Liu and M. J. Rui, "Reconstructinon of value chain, the evolution of division and the industrial structure optimization", China Industrial Economics, no. 5, pp. 148-160, 2012.

[9] J. Humphrey and H. Schmitz, "How does insertion in global value chains affect upgrading in industrial clusters", Regional Studies, vol. 36, no. 9, pp. 1017-1027, 2002.

[10] P. K. Schott, "The relative sophistication of Chinese exports", Economic Policy, vol. 23, no. 53, pp. 45-49, 2008.

[11] B. Xu and J. Lu, "Foreign direct investment, processing trade, and the sophistication of China's exports", China Economic Review, vol. 20, no. 3, pp. 425-439, 2009.

[12] Y. J. Wang, D. Sheng, B. Z. Shi, and K.W. Li, "How Does Infrastructure Affect Export Technological Sophistication", Economic Research Journal, no. 7, pp. 103-115, 2010.

[13] J. F. Francois, "Producer services, scale, and the division of labor", Oxford Economic Papers, pp. 715-729, 1990.

[14] G. L. Jia and S. H. Liu, "Producer Services: the key to constructing the National Value Chain of Chinese manufacturing", Academic Monthly, no. 12, pp. 60-67, 2012.

[15] Z. B. Liu and J. Zhang, "From integration into GVC to construction of NVC: strategic thinking for Chinese industrial upgrading", Academic Monthly, no. 9, pp. 59-68, 2009.

[16] R. Hausmann, J. Hwang, and D. Rodrik, "What you export matters", Journal of Economic Growth, vol. 12, no. 1, pp. 1-25, 2007.

[17] P. Kotler, Marketing Management (12th Edition). Shanghai: Shanghai people's house, 2006.

[18] L. Anselin, Spatial Econometrics: Methods and Models. Dordrecht: Kluw-er Academic Publishers, 1988.

[19] J. P. Cohen, Economic Benefits of Investments in Transport Infrastructure, OECD Publishing, 2007.

[20] K. N. Xu and J. Chen, "Location determinants of value chain of transnational corporations", Economic Research Journal, no. 3, pp. 138-149, 2008.

[21] G. P. Lin, Z. H. Long, and M. Wu, "A spatial investigation of $\sigma-$ convergence in China", The Journal of Quantitative \& Technical Economics, no. 4, pp. 15-22, 2006.

[22] D. Rodrik, "What's so special about China's exports", China \& World Economy, vol. 14, no. 5, pp. 1-19, 2006.

[23] G. Fan, Z. X. Guan, and Z. Z. Yao, "Analyzing the foreign trade structure based on technologies of trade goods", Economic Research Journal, no. 8, pp. 70-80, 2006.

[24] B. Xu, "Measuring China's export sophistication", China Europe International Business School, 2007.

[25] C. Z. Du and L. Zhang, "Measurement and influence factors of technological structure of exports: based on provincial panel data", China Industrial Economics, no. 12, pp. 52-64, 2013.

[26] A. Costinot, "On the origins of comparative advantage", Journal of International Economics, vol. 77, no. 2, pp. 255-264, 2009.

[27] B. Baltagi, Econometric Analysis of Panel Data. New York: John Wiley \& Sons, 2008.

\author{
Received: August 20, 2014 \\ Revised: November 07, 2014 \\ Accepted: November 21, 2014 \\ (C) Zhang et al.; Licensee Bentham Open.
}

This is an open access article licensed under the terms of the Creative Commons Attribution Non-Commercial License (http://creativecommons.org/licenses/by-nc/4.0/) which permits unrestricted, non-commercial use, distribution and reproduction in any medium, provided the work is properly cited. 